\title{
POZDROWIENIE ANIELSKIE JAKO MODLITWA
}

Pozdrowienie Anielskie w swej obecnej formie, jest modlitwa złożoną z trzech części: a) z pozdrowienia anioła Gabriela: Ave (Maria ), gratia plena, Dominus tecum $(€ \mathrm{k} 1,28)$; b) z pozdrowienia Elżbiety: benedicta tu in mulieribus et benedictus fructus ventris tui ${ }^{1}$ ), c) z wezwania Marii, dodanego przez Kościól: Sancta Maria, Mater Dei...

Nie od razu zjawia się ta modlitwa, nam dziś tak droga, w życiu Kościoła. Przez długie wieki jej nie znano i długie znów wieki przeszły, zanim otrzymała dzisiejszą formę.

1.

Pierwsze ślady wzywania Marii słowami anioła Gabriela i łaczenia równoczesnego słów anioła z słowami Elżbiety spotykamy na Wschodzie, mianowicie $\mathrm{w}$ kościele syryjskim. Patriarcha antiocheński Severus $(\dagger 528)$ podaje takie wezwanie w rytuale chrztu św. Także pewne ostrakon koptyjskie ma to zestawienie. Na Zachodzie po raz pierwszy jest ono zanotowane $\mathrm{w}$ antyfonarzu papieża Grzegorza Wielkiego († 604) jako wiersz na offertorium dla IV niedzieli Adwentu, i aż do dnia dzisiejszego offertorium to znajduje się w naszych mszałach. Później słynny teolog wschodni, św. Jan Damasceński († 749), wspomina o takiej modlitwie w jednym ze swoich kazań.

Jednakże dopiero w XII wieku zaczyna się częstsze używanie „pozdrowienia" przez wiernych, jak o tym świadczą pewne wzmianki w dziełach św. Bernarda i u św. Mechtildy. Równocześnie też zjawiaja się pobożne opowiadania o skuteczności tej modlitwy, które jako pierwszy spisuje dominikanin Tomasz z Chantipré († 1270) w swym słynnym dziele Bonum universale de apibus. Synody diecezjalne zaczynają wydawać przepisy, by "wierni obok "Ojcze nasz" i "Wierzę" także odmawiali "Zdrowaś Maria": w roku 1198 Paryż, w r. 1227 Trewir, w r. 1255 Walencja (w Hiszpanii). Tak samo przepisuja odmawianie modlitwy maryjnej kolejno wszystkie zakony, np. cystersi w r. 1221, kartuzi około r. "1230, dominikanie 1266. Z tego samego mniej więcej czasu pochodzą nagrobki, na których wyryta jest prośba, by Ave Maria odmówić za duszę zmarłego.

$\mathrm{Z}$ wzmianek historycznych wynika, że pozdrowienie anielskie stawało się powoli modlitwą chrześcijańską. Z duszy wiernych wyrywały

1) Por. wyżej art. .,Ave Maria“, str. 25--27. 
się te słowa, mające uczcić Marię, słowa zrodzone z ogólnej miłoścí do Matki Bożej, tkwiącej w sercach chrześcijańskich od wieków. I dlatego też nie przypisuje historia ich ułożenia żadnej wybitnej osobistości, one poprostu z ludu wyrosły. Jednakże do powstania "Ave Maria" przyczyniły się niewątpliwie niektóre części z t. zw. Officium parvum B. M. V., w których wystepują jako versiculi i responsoria te właśnie słowa anioła i Elżbiety. Czasowo to się zgadza, bo officium to powstało w X wieku a przez św. Piotra Damiani († 1072) zostało rozpowszechnione.Szczególnie Cystersi i Kameduli je szerzyli i oni też właśnie ,pozdrowienie anielskie" jako modlitwę ogólnie u siebie zaprowadzili. Dominikanie jako pierwsi zaprowadzili około r. 1250 zwyczaj rozpoczynania godzin Officium parvum modlitwą Ave Maria...

$\mathrm{Na}$ rozpowszechnienie modlitwy maryinej ogromnie wpłynął także zwyczaj dzwonienia na Anioł Pański. Około roku 1300 zaczęly dzwony każdego dnia wieczorem a później także rano wzywać wiernych do odmawiania Ave Maria ${ }^{2}$ ). W r. 1456 papież Kalikst III kazał także w południe dzwonić, by za przyczyną Marii wybłagać odwrócenie niebezpieczeństwa tureckiego ${ }^{3}$ ).

2.

Pierwotne "Pozdrowienie Anielskie" nie zawiera ani słowa Maria po Ave, ani Jesus jako zakończenie. Dodatek Maria już mamy w Antyfonarzı wyżej wymienionym papieża Grzegorza. W tej oto formie: Ave Maria, ... ventris tui pozdrowienie przyjęło się ogólnie w XII i XIII wieku. Jeżeli za czasów św. Dominika (†1221) odmawiać zaczęto 150 Ave - na wzór 150 psalmów psałterza - to odmawiano je w tej krótkiej formie i z takich krótkich „Zdrowaś Maria" składał się pierwotny różaniec.

Od XIV w. zaczęto dodawać ,... ventris tui. Amen“ lub Jesus. Amen, względnie Jesus Christus. Amen. Zakończenie ostatnie przypisywano papieżowi Urbanowi IV († 1264), lecz z całą pewnością tego historycznie nie stwierdzono. Warto też wspomnieć, że słowami: Je-

$\left.{ }^{2}\right)$ Dzwon wieczorny był sygnałem na gaszenie ognia $w$ domach. Ku uczczeniu zwiastowania Marii zaprowadzonю odmawianie Ave Maria. Dzwon poraniny miał czcić Marię jako M. B. Bolesną, klęczącą u stóp krzyża.

3) Zwyczaj dzwonienia trzykrotnego każdego dnia, rano, w poludnie i wieczór, datuje się dopiero z XVI w., a w przeciągu w. XVII zostal przez synody wprowadzony w poszczególnych krajach. 
zus Chrysíus. Amen kończa się trzy najstarsze teksty polskie pozdrowienia anielskiego z XV wieku."

Zakończenie dłuższe:

a) sancta Maria, ora pro nobis jest stwierdzone dla XIII wieku w brewiarzu kartuzów;

b) sancta Maria, ora pro nobis peccatoribus. Amen zachodzi w innym brewiarzu kartuskim z XIV wieku i w kazaniach św. Bernardyna $z$ Sieny $(\dagger 1444)$;

c) dalszy dodatek: nunc et in hora mortis nostrae występuje juz okolio r. $1350 \mathrm{w}$ brewiarzu kartuskim, w późniejszym brewiarzu rzymskim ( $\mathrm{x}$ XIV lub XV w.), a już częściej okolo roku 1500.

d) mamy także zakończenie podwójne, mianowicie $\mathrm{w}$ rękopisie nr 3729 Biblioteki Czartoryskich, str. 383, pisanvm po roku 1479: ... ventris tui Jesus Christus. Amen. Sancta Maria, Mater Dei dulcissima, ora pro nobis peccatoribus nunc et in hora mortis nostrae. Amen.

Pozdrowienie anielskie, identyczne zupełnie z formuła dzisiejsza, skonstatowano w Kazaniach słynnego teologa dominikańskiego, dzialającego w Ingolstadt i Budapeszcie, Piotra Nigri ( $\dagger$ 1484), w jednym $z$ dzieł Savonaroli ( $\dagger$ 1498) i w brewiarzu Kamedułów z r. 1514. $\mathrm{Czy}_{\text {zy ono }}$ tej formie ułożone zostało we Włoszech, jak sądzi Kramp ${ }^{5}$ ), nie jest zupełnie pewne, ale że $w$ Rzymie $i \mathrm{w}$ kościele włoskim najwcześniej się przyjęło, zdaje się nie ulegać wątpliwości.

Najstarszy tekst polski całej formuły pozdrowienia anielskiego mamy na kartce pergaminowej, dolepionej przy końcu inkunabułu, zawierającego traktat Mikołaja z Błonia De Sacramentis, a znajdującego sie w Bibliotece Czartoryskich w Krakowie. Traktat nosi datę: Argentorati 1487, czyli dopisek pochodzi z końca XV lub początku XVI wieku. Tak oto brzmi ten ciekawy dla nas tekst ${ }^{8}$ ):

a) Zdrowa, Maria, miłości pelna, Bóg z toba, blogoslawionaś ty między niewiastami $i$ blogoslawion owoc żywota twojego, Jezus. módl się za nami, za grzesznymi,

b) Święta Maria, Matuchno Boża najsłodsza, ninie i czasu śmierci naszej. Amen.

1) Por. teksty u W i e,r c z y ńs ki e g o, Wybór tekstów staropolskich², Warszawa 1950, str. 50.

๖) Lexikon für Theologie und Kirche $\mathrm{I}, \mathrm{k} .864$.

-) Por. Bystroń: w Pracach Filologicznych I, str. 352. 
Obok wypisany tekst niemiecki Ave Maria ma jeszcze zakończenie krótsze: Jesus Christus. Amen.

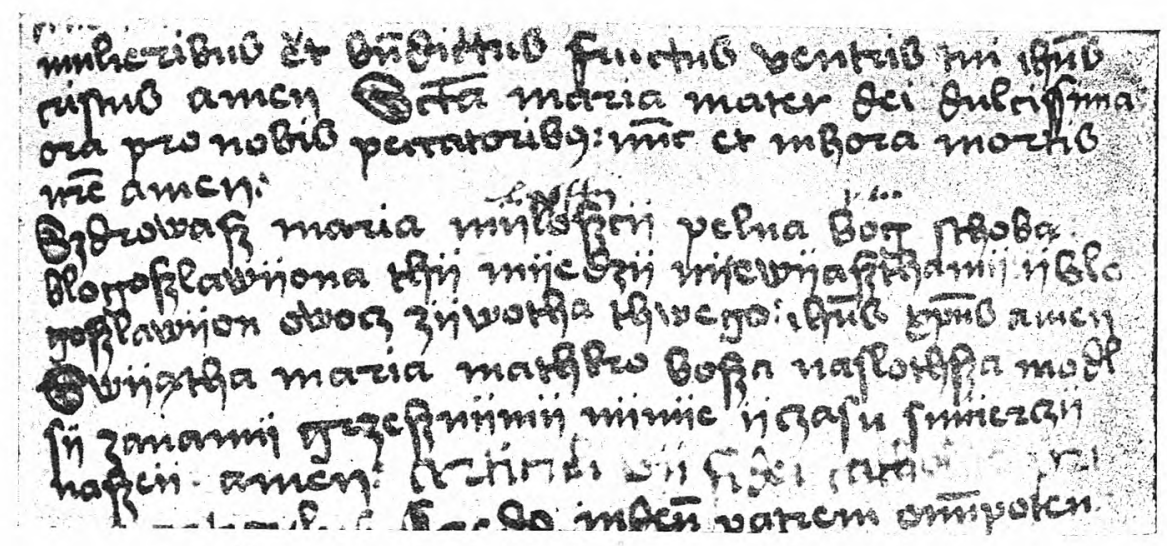

Ave Maria z kartki pergaminowej w Bibl. Czartoryskich

Z tego samego czasu pochodzi Zdrowaś Maria, zawarte w wspomnianym wyżej rękopisie nr 3729 Biblioteki Czartoryskich, lecz tym się wyróżnia, że tak samo, jak dołączony tekst łaciński, ma podwójne zakończenie (por. rkp. str. 383):

... owoc żywota twego, Jezus Chrystus. Amen.

Święta Mario, Matko Boża najsłodsza,

módl się za nami grrzesznymi,

ninie i czasu śmierci naszej. Amen.

3.

Definitywne ustalenie formuły nastąpiło przy reformie brewiarza za papieża Piusa V w r. 1568. Oficjalnie zaprowadzono teraz obowiązek odmawiania przed każda godziną kanoniczna obok Pater noster (i Credo) także Ave Maria, a tekst ustalono według formuły, obowiązującej po dzień dzisiejszy. Od kapłanów wierni tekst przyjęli. W niektórych okolicach przyjął się zwyczaj, że rodzice chrzestni przy chrzcie odmawiają obok Ojcze nasz i Wierzę także Zdrowaś Maria - zwyczaj datujący się częściowo z wieku XIV - lecz Rituale Romanum uznaje przy chrzcie tylko odmawianie Pater i Credo.

Krótsze pozdrowienie anielskie, to znaczy bez dodatku modlitewnego, jest jednak nadal używane w kościele greckim i w zakonie 
Serwitów (założonym w r. 1233), tak samo w officium parvum, odmawianym przez braci i siostry III zakonu św. Dominika.

Od XVI wieku Ave Maria stanowi inteǵralna czesśc pacierza poran nego i wieczornego. W epoce reformacji było odmawianie modlitwy maryjnej nieraz przez protestantów atakowane, ale ponieważ wzywa-

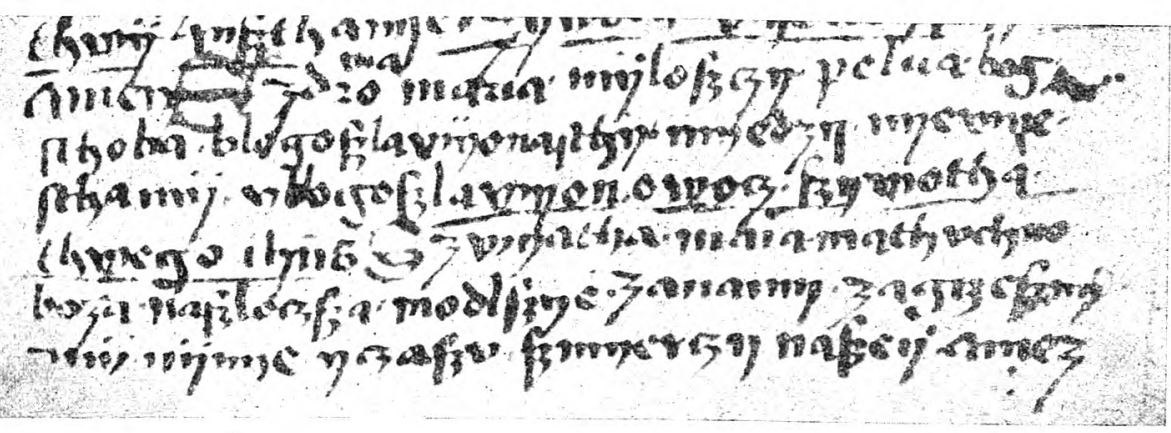

Rękopis nr 3729 Bibl. Czart.

nie Marii stanowiło specjalną cechę pacierza katolickiego, dlatego też Ave Maria tym więcej się przyjmowało i tym goręcej je kochano. A dzwony - począwszy od drugiej polowy XVI wieku - codziennie wzywaja wiernych, by rano, w poludnie i wieczorem czcili Marię pozdrowieniem anielskim ${ }^{7}$ ).

Kraków

IRENA WESTERSRA

\section{SEYNNY MARIOLOG POLSKI: O.JUSTYN ZAPARTOWICZ (Miechowita) O. P.}

Wśród wyrazów hołdu składanego Bogurodzicy $z$ racji nowoogłoszonego dogmatu Jej wniebowzięcia, wypada poświęcić kilka słów Miechowicie, jako temu, który przez całe swe życie sławił imię Marii i pozostawił po sobie zapoznane u nas duże dzieło, poświęcone wykładowi litanii loretańskiej. Pracą tą wysunął się na czoło polskich mariologów.

7) Por. dokładniejsze dane w artykule O. B e r l i èr e, Angélique (Salutation) w Dictionnaire de Théol. Cath. I (Paris 1935) col. $1273 \mathrm{mn}$. i art. Angelus tegoż autora tamże col. 1278. Tam także podana dokładniejsza bibliografia. 